\title{
Problems of Legal Competency of Innovative Infrastructure Subject within the Format of Assistance to Entrepreneurship in Forestry Legal Relations: Expediency of European Union Experience Implementation
}

\author{
Anna Liubchych ${ }^{\mathrm{a}}$, Olena Savchuk ${ }^{\mathrm{b}}$ and Tetyana Berkutova ${ }^{\mathrm{c}}$
}

\begin{abstract}
At present there is observed a change in world economy and development of evolving market relations in society alongside the transition of economy to innovative mode of development. Innovation infrastructure subjects act as obligatory participants of innovative relationships. According to the Law of Ukraine "On Investment Activity", art.5, the subjects of innovative activities are physical and (or) juridical persons of Ukraine, physical and (or) juridical persons of foreign states, persons without citizenship, associations of the mentioned persons who conduct innovative activities in Ukraine and (or) involve property and intellectual values, invest their own or borrowed finances for realizing innovative projects in Ukraine ${ }^{1}$. Entrepreneurship is considered a leading component in the processes of stable development of forest resources under conditions of market liberalization of utilizing natural resources and forest in the EU. Attracting investments to this sphere is to be based on recognition of all kinds of forestry operations as business activities with corresponding remuneration of these activities' results. Besides, improvement of financial mechanism is an integral condition of ecologically balanced use of forestry, because at present it acts as an impeding factor of efficient development of forestry into the EU countries. Investment provision improvement is possible under favorable credit and financial preconditions for financing the processes of restoring forest resources potential. It is possible to improve investment attractiveness of forestry business, especially for foreign investors, on the premise of real implementation of elements of modern ecological management into business practices.
\end{abstract}

Keywords: EU countries, foreign experience, entrepreneurship, forests, forestry legal relations, innovations, innovative activities, innovative infrastructure, subjects.

\section{Introduction}

Aim of the article is a research on innovation infrastructure subjects and their competency on the experience of European countries within the format of assistance to entrepreneurship in forestry legal relations.

As subjects of law are meant individuals, organizations, citizens' associations who can act as bearers of subjective rights and obligations due to juridical norms ${ }^{2}$.

${ }^{1}$ Law of Ukraine "On investment activities". The Verkhovna Rada Bulletin, 2002, no 36, p. 266.

2 Alekseiev S.S. The theory of law issues, vol. 1, 1972, 395p.

ascientific Secretary of Institute, scientific associate, Scientific and Research Institute of Providing Legal Framework for the Innovative Development National Academy of Law Sciences of Ukraine.

${ }^{b}$ Scientific Associate, Scientific and Research Institute of Providing Legal Framework for the Innovative Development National Academy of Law Sciences of Ukraine.

"Associate Professor of National Technical University "KhPI". 
According to O.Yu. Yakimov, it is expedient to understand as a subject of law an abstract person (physical or juridical one) supposed by legal norms and vested in a certain volume of abstract juridical rights and obligations ${ }^{3}$. This point of view is supported by V.M. Yermolenko who considers a subject of law as a generalized, combined image of a person whose constitutive quality is a general capacity of being vested in subjective rights and obligations without their specification. The specified notions of physical and juridical persons act as generic notion, while a subject of law is a generic notion that is formed under influence of more specific ones. Lawmakers, by using the juridical fiction method, equal a juridical person to physical one, thus vesting it with the status of a subject of law ${ }^{4}$.

In forestry legislation, it is impedient to distinguish main subjects having immediate interests, as well as auxiliary subjects. Thus, the main subjects of forestry legal relations include juridical and physical persons. Juridical persons are comprised of enterprises, offices, organizations, joint ventures, international associations and organizations comprised of Ukrainian and foreign juridical persons, enterprises belonging to foreign investors. Physical persons include citizens of Ukraine, foreign citizens, as well as individuals without citizenship ${ }^{5}$.

In forestry legislation, juridical persons can be conventionally subdivided into state-owned and private. Private juridical persons, according to art. 12 of Forestry Code of Ukraine, are those who have obtained free of charge, or bought for ownership closed forested plots of land with total area up to 5 hectares as part of lands of individual, farming, or any other agricultural enterprise, or forests planted by them on the acquired plots of degraded lands and lands with insufficient productivity in accordance with legislation, state-owned juridical persons in forestry legislation of Ukraine include: 1) state forestry enterprises; 2) forestry and hunting enterprises; 3) hunting areas; 4) forestry-industrial and other enterprises; 5) national parks; 6) nature reserves. Stateowned juridical persons in forestry legislation of Ukraine include: 1) state forestry enterprises; 2) forestry and hunting enterprises; 3) hunting areas; 4) forestry-industrial and other enterprises; 5) national parks; 6) nature reserves.

Also, state-owned juridical persons include Ukrainian Science-and-research Institute of Forestry and Soil-and-forests Melioration after G.M. Vysotsky (hereinafter "UkrNDIlga") which is comprised of 6 research stations, 1 research forestry, and 2 science-and-research institutes; Ukrainian Science-and-research Institute of Mountain Forestry after P.S. Pasternak (hereinafter "UkrNDIgirlis"); Ukrainian State Designing and Forest Surveying Industrial Association (hereinafter "VO Ukrderzhlisproekt") which includes Lviv and Kharkiv forest surveying expeditions; Ukrainian Center of Training, Further Training, and Qualification Raising of Foresters (hereinafter "Ukrtsentrkadrylis"); Ukrainian State Designing and Surveying Forestry Institute (hereinafter "Ukrdiprolis"); Kharkiv State Designing-and-surveying Institute of Soil Melioration and Forestry (hereinafter Kharkivdiproagrolis"); Shatsk National Nature

\footnotetext{
${ }^{3}$ Yakimov A.Yu. The status of a subject of law (theoretical issues). The state and law, 2003, no 4, pp. $5-10$.

${ }^{4}$ Yermolenko V.M. Property relationships of private agricultural enterprises: theory, legislation, practice: A monograph. Kyiv, Master of the XXI century publ., 2005, 304 p.

${ }^{5}$ Savchuk O.O. Procedural relationships in forestry legislation of Ukraine: a monograph. O.O.Savchuk. Edited by A.P. Hetman. Kharkiv: "Finart" Publ, 2016, 242 p.
} 
Park; State Organization "Ukrainian Forestry Selection Center"; State Specialized Forestprotection Enterprise (hereinafter "Kharkivlisozahyst"); State Specialized Forestprotection Enterprise (hereinafter "Vinnitsyalisozahyst").

Scientific activity of UkrNDIgirlis (Ivano-Frankivsk) is conducted on the territory of Carpathian region (Ivano-Frankivsk, Trans Carpathian, Lviv, and Chernivtsi areas). Here they've created a research and an experimental bases which include the Transcarpathian branch of UkrNDIgirlis (Mukacheve), Mountain science-and-research branch (Zelena settlement), hydro-monitoring stations. The research network of UkrNDIlga and UkrNDIgirlis covers all climatic zones of Ukraine as well as unique objects of forestry science, many of which were established more than 150 years ago. In 2004, by common decision of the Presidium of the National Academy of Sciences of Ukraine (NAS of Ukraine) and State Committee of Forestry of Ukraine, the institutes UkrNDIlga and UkrNDIgirlis obtained the status of scientific institution of double subordination: to State Committee of Forestry (now State Forestry Agency in respect to financial and business activity) and to NAS of Ukraine (in respect of science and methodology). Scientific research by subordinate branches of UkrNDIlga and UkrNDIgirlis encompass fundamental and applied aspects. Apart from budget-financed researches, the institutes conduct studies on creating science-and-technical products by contracts with organizations and enterprises subordinate to both the same agency and other agencies as well.

Forestry scientific institutions possess a large research base on whose objects most of research is performed. About one third of total research is conducted on the premises of permanent stationary research objects that are located not only on the lands of the institute's research network, but also in the forests of the branch enterprises. At present, there are about 1100 such objects with total area of nearly 4 thousand hectares. Scientific activity of these stations keeps growing. Science-and-research institutes of the branch pay considerable attention to strengthening and broadening contacts with international institutions, to participating in international projects. UkrNDIlga and UkrNDIgirlis are members of the International Union of Forestry Research Organizations (IUFRO), UkrNDIlga is a member of the European Forestry Institute. The scientists of both institutes cooperate with scientific institutions of Belarus, Poland, Slovakia, Czech Republic, Finland, Holland, Austria, Switzerland, the USA, Germany, and others.

UkrNDIlga is the National Coordinating Center of forest monitoring. It conducts research by European and American programs of forest monitoring. Scientists from UkrNDIlga and UkrNDIgirlis take part in activities of European working networks EUFORGEN on preserving genetic resources of the main deciduous trees. Branchrelated science-and-research institutes train specialists of highest qualification at postgraduate faculties.

At UkrNDIlga there functions the specialized scientific council on dissertations indexed 06.03.01 - forest cultures and phytomelioration, 06.03 .03 - forest studies and forestry. UkrNDIlga publishes a scientific works journal "Forestry and agro-forestmelioration" which is included in the international science-and-technical database Index Copernicus International (ICI). 
Scientific research of the institutes supposes development of new normative documents for the forestry branch (rules, procedures, instructions, recommendations, etc.) to improve conduction of forest-utilizing activities by enterprises on the basis of balanced development ${ }^{6}$. According to the Provision on Oblast (area) Offices of Forestry and Hunting Plots, State Agency of Forest Resources of Ukraine approved by order of Ministers of Agrarian Policies and food Supply of Ukraine of 21.03.2012 No 134, oblast offices of forestry and hunting plots are subordinate to the State Forestry Agency of Ukraine, being its territorial organs. Heads of local state administrations coordinate the work of the Offices and assist them in performing the tasks delegated to these bodies ${ }^{7}$.

\section{Characteristics of Executive Authorities as Management Subjects}

Also, to the subjects of forestry law should be referred the executive power bodies of forestry management with special competencies: 1) State Agency of Forest Resources of Ukraine; 2) the Ministry of Ecology and Natural Resources of Ukraine; 3) the Ministry of Agrarian Policies and Food Supply of Ukraine.

State Agency of Forest Resources of Ukraine, according to the Edict of the President of Ukraine "On Regulations of the State Agency of Forest Resources of Ukraine" of April 13, 2011 No 458/2011, is the central body of executive power whose activity is directed and coordinated by the Cabinet of Ministers of Ukraine and which belongs to the system of central bodies of executive power through the Minister of Agrarian Policies and Food Supplies and ensures realization of state policies in the sphere of forestry and hunting. The main missions of State Forestry Agency of Ukraine are: 1) bringing in proposal concerning formation of state policies regarding forestry and hunting; 2) realization of state policies regarding forestry and hunting ${ }^{8}$.

Forestry management at local level is performed by state enterprises that belong to the sphere of State Agency of Forest Resources Management and are coordinated by its territorial body (24 oblast Offices of Forestry and Hunting). Besides, this body controls state wood processing enterprises, scientific, training organizations, national reserves and nature parks, and other enterprises, offices, organizations immediately subordinated to it. In total, State Agency of Forest Resources of Ukraine coordinates the activities of 414 enterprises, offices, and organizations, of them forestries - 272, forestry-and-hunting enterprises -50 , hunting plots -10 , wood-processing and other enterprises -13 , national parks -5 , nature reserves $-78^{8}$.

The Ministry of Ecology and Natural Resources of Ukraine (Minpryrody of Ukraine) is the central body of executive power whose activity is directed and coordinated by the Cabinet of Ministers of Ukraine. Its activity Minpryrody of Ukraine conducts in the

6 Forestry science and innovations. (web-resource), access mode: https://tlu.kiev.ua/nasha-dijalnist/profsiino-prolis/lisova-nauka-ta-innovaciji.html.

${ }^{7}$ Statute on oblast forestry and hunting offices of State forest resources agency approved by the Order of Ministers of agriculture and food supply of Ukraine of 21.03.2012 No 134: Official Bulletin of Ukraine, 2012, no 37, art. 1408.

${ }^{8}$ Decree of the President of Ukraine "On the Statute of the State agency of forest resources of Ukraine" of April 13, 2011 No 458/2011. Official bulletin of the President of Ukraine of 20.04.2011, no 11, art. 621. (As of 01.03.2014 it controls 68 per cent of Ukraine's forests) Web-resource. Access mode: http://dklg.kmu.gov.ua/forest/control/uk/publish/article?art_id=6294\&cat_id=34019 
sphere of environment protection, ecologic safety, handling wastes, hazardous chemicals, pesticides and agrochemicals, as well as performing state ecology expertise.

The ministry has plenary powers in the spheres of atmospheric air and ozone layer protection, rational use, restoration and protection of flora and fauna, recultivating and protection of lands, restoration and protection of water (surface, subterranean, sea water) and rational use of water resources. Besides, the ministry ensures normative and legal regulating of water-related economic activities and land melioration, geologic studies and rational use of mineral resources, control of nature-protection laws observation?

According to part 4, para 5 of the Regulations on the Ministry of Ecology and Natural Resources, approved by the Edict of the President of Ukraine of April 13, 2011 No 452/2011, the mission of the Minpryrody in the sphere of rational use, restoration and protection of fauna and flora, bio- and landscape diversity, forming, preserving, and using the ecology system and within its competency the issues of biological and genetic safety, restoration and protection of lands, is approval of estimated volumes of timber harvesting, wood logging, wood cutting for state purchasing, as well as approval of forestry-related materials.

The Ministry of Agrarian Policies and Food Supplies in accordance with the Regulations approved by the Edict of the President of Ukraine of April 23, 2011 No 500 has the missions of formation and ensuring realization of: 1) state agrarian policies directed at development of agro-industrial complex and ensuring security in food supply for the state; 2) state policies in the spheres of agriculture, cattle-farming, gardening, seed-growing, seed-plotting, vine-growing, food and processing industry, engineeringand-technical support of agro-industrial complex and agricultural machine-building, agricultural advising; 3) state policies in the branches of fishery, and fish-processing industry, protection, use and restoration of live water resources, fishing regulation and traffic safety of fishing vessels; veterinary medicine, foods and fodders safety, in the spheres of quarantine and protection of plants, protection of rights on plants sorts; 4) state policies concerning the issues of land relations, topographic, geodesic, and cartography activities, forestries and hunting lands, quality and safety of agrarian products, seeds and planting material, biological and genetic safety of agricultural plants and animals, soils fertility ${ }^{10}$.

The sole state forest-surveying organization in the state is Ukrainian State Designing Forest Surveying Industrial Association (hereinafter VO “Ukrderzhlisproekt”) which is immediately subordinated to Derzhlisagenstvo (State Forestry Agency).

At present, two categories of forests inventorying are performed: industrial (basic forest surveying) and operational (continuous forest surveying). Basic forest surveying is the basis for development of the organization's perspective projects and forestry development for 10 years.

The main mission of continuous forest surveying is maintaining information data on forest resources in actual state. On materials of basic and continuous forest surveying, sectional and geo-spatial databases on forest resources are formed and maintained in actual state. The sectional taxation database and geo-spatial (cartographic)

\footnotetext{
${ }_{9}^{9}$ Web-resource. Access mode: http://www.menr.gov.ua/.

${ }^{10}$ Statute on the Ministry of Ecology and Natural Resources approved by the Decree of the President of Ukraine of April 13, 2011 No 452/2011: Official Bulletin of Ukraine, 2011, no 31, art. 1326.
} 
database have been created for nearly all the forests subordinated to Derzhlisagenstvo, as well as for considerable area of other users' forests. Databases are a component of information support of forestries' stable development and forest management, and are widely used in production and science spheres.

VO "Ukrderzhlisproekt" also conducts operations that are not directly related to forest surveying, but broaden information support of forest industry: maintaining of hunting areas; ecological monitoring of $1^{\text {st }}$ class forests; forest-soil typological examination of forest soils; detailed forest-pathologic examination of forests; fire prevention works in forests; special maintenance of recreational forests and objects of nature reserves fund with designing of corresponding projects; topographic and geodesic works and special mapping of forests; development of applied programming products; science-and-research work. The main directions of VO "Derzhlisproekt" development are introduction of modern geo-information technologies in forest surveying and forestries, adoption of new forests inventory technologies, ecological monitoring of forests' condition, supervising the introduction of projects on forestries organizing and development into production. Introduction of modern geo-information systems broadens the possibilities of forest resources' estimation through formatting various thematic maps, obtaining varied additional information, forecasting dynamics of forest resources at different scenarios of forest processing organization, modelling of surfaces and topographic cross-sections, and enables ensuring stable forestry management at all levels (forestry, forest processing enterprise, oblast (area), State Forest Agency) ${ }^{11}$.

The Concept of reforming and development of forestry in Ukraine and the Concept of national ecology policies of Ukraine until 2020 suppose improving organization-and-economic mechanisms of forestry operation on market basis, ensuring further development of business-directed forest management.

In particular, the "Concept of forestry reforming and development" supposes designing criteria (indicators) of forest management efficiency; increasing territory forestation to scientifically grounded level; increasing forests' resource and ecologic potential; improving finance-and-economic mechanism; ensuring self-recoupment and profitability of forest management, etc. To achieve the set tasks the document supposes gradual restructuring of inefficient forestry enterprises by means of their separation and creating wood-processing enterprises (subsidiaries) and selling them wood on market terms; combining measures of state assistance with introduction of the market mechanism; creating competitiveness environment in the sphere of providing services to forestry. There is accentuated the need in legal regulation of issues concerning target allotment of lands for protective forestation; ensuring state support for planting protective and field-protecting hedges that are privately and community owned ${ }^{12}$.

\section{Adaptation and Reform of Forestry Development at the Legislative Level}

According to the requirements of the EU, the issue of adaptation of Ukrainian legislation to the legislation of the countries of the European community was adopted by

11 Forestry science and innovations. (web-resource), access mode: https://tlu.kiev.ua/nasha-dijalnist/profsiino-prolis/lisova-nauka-ta-innovaciji.html

${ }^{12}$ On approving the Concept of forestry development reforming. Official Bulletin of Ukraine, 2006, no 16, art. 1207. 
the Concept of forestry reform and development of Ukraine and the Concept of national ecology policies of Ukraine until 2020 expresses. In its turn, the need of forestry "ecologizing", introducing the systems of total responsibility in forest resources sphere, harmonious combination of state and market mechanisms of forest use, institutional ensuring of rational use and restoring of forest resources on the market basis ${ }^{13}$.

The unsatisfactory state of forest resources sphere by ecological, ecologyeconomic, and social parameters enables to conclude on inefficiency of the current state form of forest management. This stipulates reasonable interest in new organizational forms of business initiatives development in forest resources sphere: state-and-private partnership, ecologically oriented forest cooperatives, social entrepreneurship of forestecology direction, cluster-type integrated business associations ${ }^{14}$.

One of forms of forest management ecology-directed business activities is state entrepreneurship on the basis of using market- and non-market mechanisms of forest management to impart more ecologically directed and socially oriented character to restoration processes in the forest resources sphere. Nowadays there exist different positions as to future scale of developing state management in the forest resources sphere on ecology-economic basis: from the point of view that it has to be reduced, to the idea of considerable broadening its limits. State management in the sphere of forest resources should create a complex of institutions which would ensure eco-systematic approach to forest industry, restoration of social good and forest resources services with participation of state capital ${ }^{15}$.

In national practice, business activity regulation in forestry ignores the positive experience in reforming forestries in Poland, Lithuania, Latvia, Estonia, Czech Republic, and Hungary, as well as other developed countries like Finland, Sweden, and Germany, which supposes the necessity in separating those functions in forestry that have a high conflict level, use of private initiative by attracting outside contractor organizations to forest works through tender procedures, selling all unprocessed wood through stock trade that enhances profit increase for regular forest users, and ensures functioning of a transparent competitive wood market ${ }^{16}$.

Ecology-economic regulation of forestry entrepreneurship is a complex of finance-economic, organizing-managerial, ecology-technical, and social measures by forest resources management bodies, non-commercial organizations, and institutions of state-private partnership directed at ensuring economically efficient and ecologically harmless forestry management. Interference of state authorities in forestry enterprises' activities may take place in three forms: direct intrusion (immediate state administration), indirect economic stimulation conducted in the form of creating stimuli (through granting various tax, customs, and other preferences and privileges), and financing

\footnotetext{
${ }_{13}$ On approving the Concept of the national ecology policies of Ukraine to 2020. Official Bulletin of Ukraine, 2007, no 79, art. 2961.

${ }^{14}$ Mishenina G.A. Ecology-economic basis of entrepreneurship development in the forest resources sphere: Dissertation thesis for Candidate of economic sciences. Sumy, 2010, 260 p.

${ }_{15}$ Mishenin Ye., Mishenina G. Conceptual foundations of state-private partnership mechanisms development in the forest resources sphere. Economist, no.12 (December), 2010, pp. 23 - 26.

${ }^{16}$ Golyan V.A., Demydiuk S.M., Gordiychuk A.I. Improvement of ecology-economic regulation of forest management business: national reality and expediency of foreign experience implementation. Investments, practice, and experience, no. 12/2012, pp. $26-28$.
} 
forestry activities, ensuring conditions of market self-regulation (which means creating competitive equal conditions for all forest managing subjects and application of such market mechanisms as free pricing, stock market trade, attracting outside organizations for performing a stipulated list of forest managing operations ${ }^{17}$.

Practices of European countries, which suppose active forest management activities on lands of nature reserves, that broadens territorial and resource base of forestry business development, creates additional financial base for more efficient use of forest's non-raw material qualities. Such practices are to be adopted in Ukraine in middle-term perspective because application of such market mechanisms as free pricing, stock market trade, attracting outside organizations for performing a stipulated list of forest managing operations ${ }^{17}$.

Forestry policies of the European Union concerning development of stable management of forest resources are based on the principles, which were proclaimed at the United Nations' Conference on Environment and Development (Rio de Janeiro, 1992), by the European parliament at conferences of ministers in Strasbourg (1990), Helsinki (1993), Lisbon (1998), Vienne (2003), Warsaw (2007) and was reflected in such well-known documents as "Strategy", "the Union's Program on Forestry" (1998) and "the Strategy of the European Union in Forestry" (1997). An important point of the EU strategy in forestry is proclamation of a struggle with erosion, deforestation, fires, and degradation of bio-diversity, as well as integration with the policies concerning environment protection and agriculture development that supposes introduction of efficient stimuli directed at agro-forestry management ${ }^{17}$.

An important direction of the forest resources sphere development is formation of business-integrated structures in agriculture and forestries. Thus, at the World Forestry Congress, which took place in Turkey (October 1997), special attention was paid to the problem of integrating agriculture with forestry in order to achieve a balanced land cultivation and stable development of the world economy ${ }^{18}$.

Under conditions of market liberalization of use of nature and forestry management, one of the leading roles in the processes of attaining stable forest resources development is obviously to be given to entrepreneurs as a powerful, mobile, and active element of market transformations in all spheres of public economy. On condition of existence of civilized and efficient institutionally-regulating forest-management mechanisms, business subjects could (through realizing private initiatives) involve with greater efficiency forest resources and their qualities (ecological, social, cultural, and so on) into the system of commodities-and-money relations, ensuring thus formation of financial base for restoring and renewing forests resources potential. It is also possible to say that efficient and fruitful realization of forestry ecology-economic and social interests of business subjects in forests resources sphere supposes creation of new organizationaleconomic and institutional-regulating conditions for industrial forest management on ecology-economic base ${ }^{19}$.

\footnotetext{
${ }^{17}$ Syniakevich I. Eco-policy instruments: theory and practice. Lviv: ZUTsK Publ., 2003, 188 p.

${ }^{18}$ Kozhukhov N.I. Modern level of business activity in the forests of agricultural organizations. Forestry, 2004, no 4, 480 p.

19 Mishenin Ye.V., Mishenina G.A., Yarova I. Ye. Ecology-economic and social points of forestry development on entrepreneurial basis. Sumy National Agricultural University Bulletin. "Economy and management" series, edition. 3 (51), 2012, pp. 3 - 10 .
} 
An important direction of the forest resources sphere development is formation of business-integrated structures in agriculture and forestries. Thus, at the World Forestry Congress, which took place in Turkey (October 1997), special attention was paid to the problem of integrating agriculture with forestry in order to achieve a balanced land cultivation and stable development of the world economy ${ }^{19}$.

Ecology-economic foundations of entrepreneurship development in forest resources sphere are determined by principles of stable multi-purpose use and restoring of forest resources as well as peculiarities of business approach to solving ecologyeconomic problems in forest management. Ecology-economic foundations of entrepreneurial forest management are formed within: 1) transformation of social paradigm of forests protection which is grounded on co-ordination of stable economyand-social development with ecologically balanced use and restoring of forest resource as well as "ecologizing" forestry economy; 2) forming state forestry policies on the foundation of stable forest management, increasing forests' resource and ecology potential; 3) gradual introduction in forest management the model of systematic forest management; 4) the need in inter-sectoral (inter-industrial) integration in the sphere of multi-purpose forest management and realization of forest's ecological function; 5) organizing an integrated multipurpose and complex use of forest resources, large-scaled forests restoring on the landscape and eco-system basis; 6) institutional transformations which determine directions of market oriented reforming of forestry; 7) co-ordination of the national forest management system in accordance with international norms and parameters which suppose, in particular, conducting ecology certification of forests; 8) forest management globalization, increasing importance of forests in preserving biodiversity and ensuring of climate improvement ${ }^{20}$.

As the main directions of entrepreneurship development in forest resources sphere, the following can be distinguished: 1. Forest restoring and forestation on the basis of ecology-oriented forestry. Taking forest management measures concerning assistance of natural restoration of forests, conducting forest-restoring woodcuts. Conducting forest culturing works by age and technological phases. Plantation forestgrowing, creating energy plantations for biofuel production (planting fast-growing woods, shortening cut periods resulting in decreasing of anthropogenic pressure on natural forests and ensuring their renewal). 2. Use of separate forest management woodgrowing operations. Forest management measures on forming highly productive plantations maximally similar to native kinds of trees. Conducting maintenance cuts and sanitary cuts (measures of forests protection from pests, pathogens; measures of fires prevention and other damage; hydro-melioration and forest draining; constructing roads for forest management). 3. Seedling production. Formation of wood-planting base (seedling plantations, plots; provision of forest seeds, growing elite seedlings). 4. Wood provision activity. Using resources of timber, non-timber, and animal origin. 5. Forest industry production. Wood processing, forest-related chemistry, food processing. Use of wastes: of wood cutting and wood processing, as well as all other kinds of wastes connected with complete cycle of forest growing, wood procurement and wood

${ }^{20}$ Mishenin Ye.V., Mishenina G.A., Yarova I. Ye. Ecology-economic and social points of forestry development on entrepreneurial basis. Sumy National Agricultural University Bulletin. "Economy and management" series, edition. 3 (51), 2012 , pp. 3 - 10. 
processing. 6. Recreation activity. Broadening and quality improvement of ecosystem services concerning the use of forests' recreation resources. Taking forest management and organizing-economic measures of preserving biodiversity and improvement of plants' gene pool. 7. Creation of protective forest plantations. Forests' re-cultivation. Creating plantations intended for water- and soil protection, for sanitary-hygienic and medicinal purposes. Agro-melioration (creating protective hedges, forestation of agricultural lands with little productivity and erosion-hazardous lands). Forming "carbon" forests. 8. Rendering ecology services. Introduction of ecological management elements (forest certification in particular), conducting ecological audit and introduction ecological insurance mechanisms, financial support of measures on forest resources restoring and protection, ecological marketing and engineering (re-engineering), consulting-and-information activity, forest control and monitoring services, training and educating, personnel's further training and qualification raising ${ }^{21}$.

Market organization of forestry industrial production that stimulates investments attraction to this sphere is to be grounded on recognizing all forestry works as business activity with corresponding remuneration of this activity's results. It is also necessary to form economy mechanisms of involving ecosystem services of social and nature preserving forests into production sphere ${ }^{21}$.

In scientific literature, there are different approaches as to introduction of new forms of entrepreneurial activities to forestry sector. Thus, some scientists see the main problem of institutionalizing of perspective forms of business in transparent reforming of ownership relations on separate components of forest resources potential. When reforming relations of ownership of natural resources it is necessary to set up quantitative and qualitative parameters of forestry objects, their ecology-economic estimations, to determine the optimum list of property holders. A complex of corresponding measures should include conducting of forest-and-land reform with diversification of ownership forms on lands of forest fund and forest resources, creation in forest sector an economic mechanism of market type as a precondition for the branch's more dynamic development and raising its efficiency; forming in the forestgrowing sphere a diversified production structure on a modern technological basis. At the same time, there are scientists who reduce entrepreneurship activation to the need in ensuring dynamic development of forest sector, rational use of forest resources potential, meeting the needs of economy and the next generation in resources, organizing a highly efficient production system with taking into account science-and-technical progress, ecology component, social justice, and preserving the environmental quality.

There also exists a thought that an important means of activating entrepreneurship in forest sector should be a renovated tax-and-budget regulation as the basis of the industry's financial resources and mechanisms. Transition to the rails of stable development supposes an increase in the income part of the budget of the share of forest resources payments, introducing a system of privileged taxation for producing items of wood wastes, loss compensation by improving the system of payments for pollution of forests over the set norms. There is also the position, which holds that entrepreneurship stimulation policy should be an organic part of the transformation measures system of forest sector's reforming, particularly reforming relations of ownership of forest resources, forests management system, introduction of modern 
organizing- and-legal forms of business activity and new forms of finance-credit support. Ukraine is capable of ensuring transition of forestry to a balanced forest management primarily on account of structural modernizing of all forest sector's components, raising efficiency of forest resources restoring, rationalizing their use, rational mobilizing of creative potential for building up all the structures of the complex ${ }^{21}$.

The currently existing organizing-and-legal forms of forest management and production not always enhance positive trends in restoring forest resources. Considerable destructive impact on forest restoring and forestation processes is caused by the factor of departmental diffusion of managerial functions concerning separate sectors of forest resources and regulating ownership rights on forest resources. In market economy, this problem becomes even more acute for forestry enterprises that operate in the most forestated areas. The agenda of today is the problem of diversification of organizing-and-legal forms of business activity which ensure efficient use of forests' resource potential and deepen specialization, simplify relations with intermediaries on forest commodities market, accelerate introduction of innovative technologies which enable gradual "ecologizing" of forest processing activity, deepen completeness of wood processing 22 .

The starting point in developing regulating levers of business activity activation in forest sector is the fact that forest is raw material and that the volume and scale of its involvement in restoring process are determined and limited by a number of objective factors. First of all, it is a considerable time lag between wood planting and timber harvesting, absence of differentiation in Traditional forest-users need being transformed into a more mobile organizing-and-legal forms which will intensify competition in the forest resources market and private initiative in forestry management, increase investments' lability, and stimulate a deeper and more complex wood processing. It is necessary to clarify the main tasks of forestry enterprises' reorganization, which, unlike traditional tasks, suppose considerable diversification of economic activity with taking accentuation from the sphere of timber harvesting to the sphere of using non-timber raw materials, non-raw-material qualities of forests and to more ecological turning of forest resources into commodity goods ${ }^{22}$.

The means of ensuring transformation of economic relations in forest sector include formation of frame conditions for this process, that is adoption of legal and normative-legal acts, as well as joining international agreements concerning forestry, organizing the system of control and appropriate reacting within normative-legal forestry and civil legislation. Ensuring forest sector's transition to the new model of development in legal aspect supposes the need in reforming the legal basis of forest sector of economy and bringing it to correspondence with market conditions of business activity ${ }^{23}$.

Formation of modern business environment in forest sector is to take place in stages. The first stage is aimed at overcoming the crisis situation in the branches of the complex, ensuring stability and creating conditions for economic growth on the basis of developing a normative-legal base, methodology and methodological approaches to

${ }^{21}$ Demydiuk S.M. Problem issues of business activity development in forest sector. National University of Aquatic Industry and Use of Natural Resources. "Economy" series, issue 1 (53), 2011, pp. 51 - 56.

${ }^{22}$ Demydiuk S.M. Problem issues of business activity development in forest sector. National University of Aquatic Industry and Use of Natural Resources. "Economy" series, issue 1 (53), 2011, pp. 51 - 56. 
reforming the complex, creating conditions for balancing production and forest consumption, improvement of ecology situation, designating priorities of renewal of rational economic ties and use of production potential for satisfying the country's own needs and export securing, primarily that of ready-made products of wood-processing industry. At the revival stage, the first in the priorities hierarchy comes technical modernization of material production, improvement of forms of forests and production management. On the basis of the use of modern technologies the issue of structural reorientation of forest complex branches should be solved with taking into account ecology problems. At the stage of growth of industry's enterprises following the completion of institutional transformations, there starts the balancing of the main components of forest sectors, in particular, of forestries, forest exploiting, and wood processing. The second stage supposes efficient solving of tasks on industry's structural renovation, reforming of property status on forestlands, forest resources, and economic potential of the industry, transition to use of mostly economy mechanisms of stimulating and regulating structural changes. The third stage supposes ensuring of stable development on the basis of the new structural units, creation of ecologically safe enterprises, satisfying economy's needs in forest resources and forestry products with taking into account ecological demands and ecology safety as a foundation of socioeconomic development ${ }^{23}$.

A perspective form of business activity in forest sector is cluster units, which are free-will associations of local authorities, Minpryrody (Ministry of nature) departments, permanent forest-users, and finance-and-credit institutions. Considering the mentioned above, such form of business activity has the minimal potential of extensive forest exploitation because it includes representatives of local authorities and state departments of environment protection that will timely block manifestations of non-sanctioned and over-limit timber harvesting. Clusters enable to co-orinate the development priorities of local forestry complexes with the problems of rural territories revival ${ }^{23}$.

Formation of entrepreneurship in forest sector calls for system approach as to forms and methods of economic activity, as well as the scales of institutionalization of non-state forms of ownership ${ }^{24}$.

Development of perspective directions of entrepreneurship development in forest sector should be based on the need in raising efficiency of economic utilizing of forests resource potential 25 .

One of factors to raise investment attractiveness of forestry enterprises would be improvement of methodologic support of conducting mortgage operations on the basis of using forestry products, especially highly liquid timber ${ }^{26}$.

Increase in investment resources concentration is also possible through consolidation of forestry enterprises into integrated business groups that should include

${ }^{23}$ Demydiuk S.M. Problem issues of business activity development in forest sector. National University of Aquatic Industry and Use of Natural Resources. "Economy" series, issue 1 (53), 2011, pp. 51 - 56.

${ }^{24}$ Koval Ya. Ownership relationships in the context of restructuring forest sector of Ukraine. Economy of Ukraine, 2001, no. 6 , pp. $63-67$.

25 Golyan V.A. Problems of business activity economic regulating in forest sector of Ukraine. Modern economy. Problems and solution, 2010, no. 5 (5), pp. $24-33$.

${ }^{26}$ Hvesyk. M.A. Institutional model of use of natural resources in conditions of global challenges [Text]: monography. M.A. Hvesyk, V.A. Golyan. Kiev: Condor Publ., 2007, 480 p. 
finance-and-credit institutions and representatives of local authorities. This will enable to raise efficiency of realization of projects connected with fulfilling state orders on construction materials and firewood for socially insecure population.

An important aspect of creating a favorable institutional environment needed for efficient development of entrepreneurship in forest sector is formation institutions of state-and-private partnership in certain areas. The most acceptable forms of state-andprivate partnership within the system of forestry relations are cluster groups and holding companies $^{26}$.

In modern conditions of management, a very important factor of efficient operation of enterprises is their resources potential, and achievement of balanced development of each industry in Ukraine depends on rational use of resources. National economy's orienting on world market's priorities includes development and formation of new approaches in the sphere of "ecologizing" business activity of enterprises on the basis of combining administrative-economic and financial methods of management. This will provide an opportunity of improving the models of regions' functioning on account of forming financial mechanisms that would ensure efficiency in use and restoring nature potential in each territorial complex.

Finance mechanism's improvement is an integral condition of ecologically balanced forest management, because imperfection of current mechanism of use and restoring forest resources is restraining factor of forestry's efficient development ${ }^{27}$.

In connection with unsatisfactory state of Ukraine's forest resources and increasing demand for ecology-economic functions of forests, the strategy of forestry development should be directed at ecologically balanced principles of economic activity. And among important tasks in this respect are restoring forests, their protection, "ecologizing" of production and economy instruments, of people's spirituality and consciousness. At the same time, an ecologically balanced forest management supposes complex, rational use of forest resources, permanent improvement of their economic, ecological, and social functions with taking into account ecology imperatives to satisfy the needs of current and future generations ${ }^{28}$.

The main factors influencing the forming of ecologically balanced forest management are economic, ecological, social, technological, institutional and natural components. Economic factors include growth of demand on forest resources, financial policies, the industry's finance-and-economy mechanism, and others. Ecological factors include the positive impact of forest on environment, its ability to restore itself, growing demand on forest's ecology services. Technological factors suppose improvement of timbering, deep processing of wood, raising mechanization level in the industry. Institutional factors are establishing various organizations and departments, legislation improvement, development of science and education, and social factors are a positive impact of forest on people's health and satisfying their needs in forest resources.

To ensure stable development of forest industry each state forms its forestry policy, which is a totality of principles and instruments that society uses for realization of its interests in forest management. Forestry policy should be directed at rational use,

${ }^{27}$ Ilnytska-Hykavchuk G. Ya. Financial mechanism of ecologically balanced forest management: Author's thesis for Candidate of economic sciences. Rivne, 2009, 22 p. 
extensive restoring of forests, preserving and protection of biodiversity, strengthening forests' ecology functions, providing forestries with necessary financial resources, finance instrument's reforming in the direction of strengthening its ecologic directedness; legislation improvement, and others ${ }^{28}$.

An important factor of rational forest management is the finance mechanism, which should be ecologically oriented due to special importance of forest resources in economy-and-ecological sphere. Financial mechanism, in its turn, includes legal, information, and normative aspects, financial levers, as well as stimulation methods. It is possible to relate to financial levers the following: 1) payments for special use of forest resources; 2) investments; 3) credit; 4) land and other taxes; 5) forest resources funds; 6) fines for violating the forestry legislation norms; 7) rent; 8) leasing; 9) insurance payments; 10) prices; 11) plans; 12) others. To stimulation methods, one can refer the following: 1) privileged taxation; 2) privileged crediting; 3) customs duties' differentiation depending on the extent of forest material's processing; 4) budget financing; 5) pricemaking; 6) ecologic insurance; 7) planning; 8) investment; 9) others. Support: 1) legal (laws, decrees, etc.); 2) information (enterprises' accountancy, etc.); 3) normative (instructions, norms, normatives, etc.) ${ }^{28}$.

The main sources of forestry financing are enterprises' own finances, state budget finances, and credits. On account of their own financial resources enterprises finance the main use cutting in full volume, while budget money are directed at forestcultivating works, forest protection, fighting pests and diseases of the forest, on logging connected with forest management, and so on. But the budget financing is allocated insufficiently and on residual principle without taking into account priority of certain forest management operations.

Considering low forestation and chiefly ecologic significance of forests in Ukraine, the state should retain budget investment in nature preserve forests, forestation of lands polluted with radionuclides and unfit for agriculture, etc. ${ }^{28}$.

Perspectives of forestry development are connected with activation of stateprivate partnership that will enable not only attracting additional financial resources for modernizing and establishing new production enterprises, but also raising innovative activity level which will be favorable for introduction of ecologically safe, energy- and resource-saving technologies at all stages of forest materials and products processing ${ }^{29}$.

Foreign experience attests that managerial functions of state bodies as to regulating forestry relationships in forest resources sphere can be concentrated either in certain specialized state bodies (ministries or agencies) or by singling out a specialized subdivision in a separate state body. Generally, the managerial structure and functions of state governing bodies apart from historic preconditions and level of societal thinking in any country depends on the extent of ownership relations development, the amount of forested land, and on the number of private forest-users. So, perspectives of private sector in forestry in Ukraine depends on how society is prepared for it and whether state

\footnotetext{
28 Ilnytska-Hykavchuk G. Ya. Financial mechanism of ecologically balanced forest management: Author's thesis for Candidate of economic sciences. Rivne, 2009, 22 p.

${ }^{29}$ Golyan V.A. State-private partnership as efficient form of entrepreneurship in forest sector. Agrosvit, 2010, no. 15, pp. 2 - 9.
} 
bodies will be able to create a viable system of economic stimulating private forest-users to raise economic and social efficiency in forest management ${ }^{30}$.

Full-fledged development of any segment of industrial complex under economic policy liberalization and institutionalizing of various forms of business activity is impossible without a developed market infrastructure where the leading role is played by finance-and-credit institutions. Forest-use sphere is no exception. Moreover, the previous experience of direct state subsidizing and allocating grants on forest management has proven the need in diversifying financial sources for forest management and forest protection works. Time calls for introduction of varied forms of capitalization of forest resources component of productive forces, and positive solving of this task depends directly on efficient activity of finance-credit institutions in forestry sphere. Considering that forest management is not as investment attractive as, say, ferrous metallurgy, there will be no special activity on behalf of finance-credit institutions concerning financing forestry projects in near future if there are no radical changes in the institutional system of forest management's finance-credit regulation ${ }^{31}$.

Accomplishment of investment projects by Ukrainian subjects of economic activity with the assistance of finance-credit institutions is one of optimum mechanisms of conducting investment activity of nature protection directedness, and it is efficient for both large and small businesses thanks to a possibility of crediting on account of attracted integrated loans from participants of specialized finance-credit institutions.

Efficient functioning of the mentioned institutions calls for corresponding state support. At present, imperfection of laws in Ukraine is aggravated by their instability. Legislation on establishing an efficient mechanism of free money accumulation within specialized finance-credit institutions for nature protection programs and rational forest use project is long since outdated.

Legislative support of realization of forest management and forest protection investment initiatives by Ukrainian subjects of economic activity with the assistance of specialized finance-credit institutions supposes not only passing of normative acts which immediately regulate these institutions' policies for crediting perspective projects in forest protection sphere, but also their optimum correspondence to the existing legislation.

Accomplishment of forest protection within forest management investment projects by subjects of economic activity with the assistance of specialized finance-credit institutions is common for states with different economic systems, but it is utmostly expedient for economies of states that are at the stage of market mechanism's development and transformation.

Introduction of specialized finance-credit institutions, credit associations in particular, in order to accomplish investment projects will enable raising the level of finance potential concentration at forestry enterprises, getting used to modern nature

\footnotetext{
${ }^{30}$ Zinovchuk N., Vasyliak N. Forest resources sphere development stimulating: system contradictions and instruments of economic relationships realization. Economist, no 12, 2012, section "Economy of the use of natural resources", pp. 52 - 54 .

31 Kapruk A. Forest management finance-credit regulating: institutional preconditions and possible alternatives. Economist, no. 3, 2011, pp. $36-38$.
} 
protection management methodology, techniques and technologies, it will enhance improvement of ecology-economic situation in areas of forestation of infertile lands ${ }^{32}$.

The budget deficit of forestry development in G.A. Mishenina's opinion prevents form ensuring diligent financial support of stable forest use and eco-systematic forest resources management. This accentuates the need in improving economy mechanism of forest resource sphere functioning, and this mechanism should be directed at attracting additional finance sources that meet market conditions of forest management ${ }^{33}$.

To the factors that decrease forestry's investment attractiveness one can also relate: unfavorable conditions for long-term investments in forestry; high corruption level of state structures responsible for distributing and use of forest resources; problems in accounting forest resources use; problems in accounting use, restoring and protection of forest resources; absence of certification of considerable share of Ukrainian forestry produce; high proportion of shadow economy in forest sector, destroying forests of special nature protection value; forest pollution at Polissia with industrial wastes and radionuclides ${ }^{34}$.

All the aforementioned problems create an unfavorable climate in forestry. The processes of forming new management methods in forest industry should suppose the use of state-private partnership mechanism. Appearing and development of state-private partnership in the sphere of forest relations is a result of search for new forms and methods of state control and regulation determined by considerable changes in the direction of forest management liberalization, its decentralizing, and which is an alternative of forests privatization ${ }^{35}$.

The main preconditions for appearing of the partnership mechanism of the state and private sectors are: diversity of ownership forms on forests and forest management; defining forests as a social and ecological good within the system of socio-economic relations; deficit in budget financing of forestry development; the need in planting new forests and protecting tree-lines; the presence of realistic projects of foresting eroded and infertile lands, as well as planting climate-protecting forests ${ }^{36}$.

32 Kapruk A. Forest management finance-credit regulating: institutional preconditions and possible alternatives. Economist, no. 3, 2011, pp. 36 - 38.

${ }^{33}$ Mishenina G. A. Rent relationships in natural resources use: modern practices and perspectives. Stable development and ecology safety of society in economic transformation: materials of the Third science-and-practical conference. Bakhchisaray, September 15 - 16, 2011, held at NDI of stable development and use of natural resources, DU "Institute of economy of nature resources use and stable development at National Academy of Science of Ukraine", the Crimean Institute of State higher education establishment “KNEU after V. Hetman”. Simferopol: Phoenix Publ, 2011, pp. 178 - 180.

${ }^{34}$ Mishenin Ye.V. Socio-ecologic responsibility of forest complex enterprises. Stable development and ecologic safety of society in economic transformations: materials of the Second science-and-practical conference. Bakhchisaray, September 23 - 24, 2010 held at NDI of stable development and use of natural resources, DU "Institute of economy of nature resources use and stable development at National Academy of Science of Ukraine", the Crimean Institute of State higher education establishment "KNEU after V. Hetman". Simferopol: Phoenix Publ., 2010, pp. 235 - 237.

35 Melnyk T.D. The mechanism of raising investment potential of a region's forestry complex. National University of Aquatic Resources and Use of Nature Resources. "Economics" series. Edition 4 (56), 2011, pp. 181 - 186.

${ }^{36}$ Mishenin Ye.V. Socio-ecologic responsibility of forest complex enterprises. Stable development and ecologic safety of society in economic transformations: materials of the Second science-and-practical conference. Bakhchisaray, September 23 - 24, 2010 held at NDI of stable development and use of natural resources, DU "Institute of economy of nature resources use and stable development at National Academy of Science of Ukraine", the Crimean Institute of State higher education establishment "KNEU after V. Hetman”. Simferopol: Phoenix Publ., 2010, pp. 235 - 237. 
In Ukraine there are quite active discussions concerning problem issues of investment support of certain sectors of national economy. These issues include, in particular: 1) the need in modernizing technic-and-technological bases of industrial production; 2) building up industrial and non-industrial infrastructure; 3) introduction of perspective forms of innovative activities; 4) use of positive experience in information support of social reproduction.

The forestry complex development calls for realization of forest resources growth projects and introduction of modern wood processing technologies. The urgency of this task is getting more acute due to: 1) insufficiency of budget financing of forest restoring operations; 2) deficit of investment resources for forest management operations; 3) "deviated" investment policy of private wood-processing enterprises ${ }^{37}$.

Making investments one should consider the complex effect that appears when money is used for restoring of forest potential. Unlike other branches of economy, forestry produces considerable positive ecology- and social effects that can significantly overcome economic effect. This makes forestry utmostly important for society in respect of creating favorable living environment, positive impact of forest on habitat, and so on $^{38}$.

Improvement of investment support for accomplishing forest management projects depends on raising their investment attractiveness and improvement of separate components of national forest policy that create favorable credit and tax preconditions for financing the projects on forest resources potential restoring. It is possible to raise forestry's investment attractiveness, particularly for foreign investors, on the basis of real incorporation into business practices the elements of modern ecological management which have long since proven their efficiency in the countries of developed capitalism. First of all, it is necessary to conduct ecological audit to get rid of artificially imposed "Chornobyl syndrome" in some areas and regions, to form methodological and information base of ecological marketing of non-raw materials qualities of forest and not only wood products, to run monitoring of nature-and-age structure of forest resources on a regular basis. Customs duties on importing resource- and energy-saving woodprocessing equipment should be decreased; by means of fiscal levers the use of methods of amortization of woodcutting and wood-processing equipment at forestry enterprises should be encouraged; demands to subjects of forestry business when granting licenses on conducting this kind of business activity should be raised ${ }^{39}$.

Financial support of investment environment in forestry development is an important component of economic mechanism that makes it possible for the industry to establish relationships with the state, forestry products consumers, and the environment. In other words, financial support should be viewed as a system of institutions connected with financial support of investment environment of forest resources development, their protection, use, strengthening of forest's social and economic functions in accordance

\footnotetext{
${ }^{37}$ Gorbyk V.M. Forestry policy forming: current state and development perspectives. Economy and State, 2006, no 11, pp. $73-76$.

${ }^{38}$ Kolisnyk B.I. Investment support of forest managing complex' development: current state and search for additional sources. Investments: practice and experience, 2008, no. 7, pp. $3-7$.

${ }^{39}$ Shubalyi O.M. Methodological foundations of the region forestries' competitive positions. Economy and State, 2010, no 1 , pp $62-66$.
} 
with demands of ecology, efficient economy, and quality of environmental nature consumption $^{40}$.

As the key institution in the institutional structure of financial support of investment environment of forestry development the institution of state ownership of forestlands and forests should be considered. This institution is the cornerstone of forest management. Also, it should be noted that the existing institutional structure of financial support of investment environment of forestry development does not meet the new challenges of economic transformation due to the presence of a large number of systematic contradictions and traps that are determined by insufficient adaptability to current market realia on behalf of the institutions that Ukraine inherited from commandadministrative system of centralized control, as well as by weak ability to get involved in the process of restoring the institutions formed as a result of transformation changes ${ }^{41}$.

Budget financing of forest sector development, both direct and indirect, considerably influences the amount of investments in forest management because: 1) the state directly finances investment activities in forestry; 2) the state can stimulate private sector's investments in forestry through setting tax preferences, giving grants and privileged credits; 3) the state is responsible for realization of private investment stimulation policy ${ }^{42}$.

Official assistance in order to develop forestry sector is conducted mainly by international organizations. The difficulty in obtaining international finance assistance for Ukraine is explained by the fact that it has the status of a state with market economy and some mechanisms applied for developing countries are not acceptable for it any longer. European integration of Ukraine opens possibilities of financial assistance on behalf of European Commission and various euro-integration mechanisms (G2G, TAIEX, Twinning, SIGMA, etc.). But this assistance is mostly methodological in character and in most cases it doesn't enable solving urgent issues of stable forest management. Considering certain limitations (directedness, approval procedure, etc.), broader opportunities are provided by using the Kyoto Protocol's flexible mechanisms ${ }^{43}$.

Private investments are a powerful source of financing, but, in most cases, they don't facilitate stable forest management without corresponding guarantees. Analysis of each component of financial support of forest sector's investment environment formation enables to conclude that transition of Ukraine's forestry sector to the stable development model supposes implementation of a number of transformation procedures. An important place among the mentioned procedures belongs to improvement of forestry's institutional structure by means of introducing new market oriented organizational forms of enterprise. Among the most perspective organizational

\footnotetext{
${ }^{40}$ Antonenko I.Ya. Formation of market-orientated finance-economic mechanism of Ukraine's forest resources sphere's development. AgroSvit: information-analytical journal, 2011, no. 13/14, pp. 7 - 12.

${ }^{41}$ Rogach S.M. Directions of balancing institutional support of Ukraine's forestry complex' development. Sumy National Agrarian National University Bulletin. "Finances and credit” series, 2013, no.1, pp. $118-126$.

${ }^{42}$ Labenko O.M. Financing of forests restoring projects. Science Bulletin of National University of Bio-resources and Use of Natural Resources of Ukraine. 181 st edition, part 5. "Economy, agriculture management, business" series: Collected works, Kyiv, NUBiPU publ., 2013, pp. 137 - 144.

${ }_{43}$ Poliakova L.V. International issues of providing financial assistance to stable forest management. Scientific reports of NUBiP, 2011, no. 4 (26), pp. 112 - 119.
} 
forms, one can distinguish formation of state-private partnership and international cooperation in forest sector investing ${ }^{44}$.

As an additional source of investment, it is possible to use the means of nonstate pension funds, which is not a violation of limitations stipulated by the Law of Ukraine "On non-state pension provision". On conditions of state-private partnership development, it will be possible to use as an additional source of forestry sector development investment the reserves of national and foreign insurance companies that should be viewed as institutional investors because their primary activity is not only providing insurance services, but also investments in order to save the accumulated money from inflation and obtain additional profit. State-private partnership development will enhance an ever wider introduction of rent financing and concession in forestry, which is characterized by a stricter control from the state of investment volumes, timeliness of payments, and other investor's obligations as to ensuring all-round development of forestry sector, social programs realization, and so on. The effect of state-private partnership in forestry sector will be that business will have attractive investment objects with guaranteed profits and the state will have economy of public resources on forests' restoring 45 .

Insufficient budget financing of forest restoring and forest renewal operations prevents forestries from restoring resource- and production potential in full volume and keeping the rules of non-extensive forest use. It is necessary to form the institutional foundation for broadening the range of sources, forms, and methods of investment support of forest management projects realization. First of all, it is expedient to create transparent conditions for attracting outside organizations to conduct forest management operations, to enlarge the list of objects of contracts between state forestry enterprises and private business structures (state-private partnership), to direct local budget finances on compensations of expenses by subjects of forestry activity on obtaining modern forest equipment and extending forestlands. These measures will enhance raising capitalization level of forestry budget, accelerate the rate of forest potential increase, ensure creation of new work places and ultimately lead to acceleration of rates of socio-economic growth ${ }^{46}$.

\section{Conclusions and Proposals}

To enhance entrepreneurship development in the sphere of national forestry relations through implementing positive foreign (primarily European) experience, it is expedient to implement the following proposals.

1. Forestry needs renewed, modern, directed at the best foreign experience directives for vocational training of forestry specialists (forest managers) who would possess deep theoretical knowledge and practical skills to be used at work in situ.

2. Forestry operators should run forestry in a balanced manner, taking into account its economic, ecological, and social significance for society, avoiding aggravation of certain

\footnotetext{
${ }^{44}$ Shumliansky B.F. Financial support as a foundation of forming investment medium for forest sector development. Investments: practice and experience. Economic science, no. 15/2015, pp. 61 - 66.

${ }^{45}$ Melnyk T.D. The mechanism of raising investment potential of a region's forestry complex. National University of Aquatic Resources and Use of Nature Resources. "Economics" series. Edition 4 (56), 2011, pp. 181 - 186.
} 
contradictions and problems that arise in the sphere of preserving, use, and restoring forest resources, they should also create a really transparent wood market as well as a competitive environment for private capital.

3. Forestry policies should be directed at rational, non-extensive use, extended restoring of forests; preserving and protection of bio-diversity; strengthening forests' ecology functions; provision of forestry with necessary financial resources; reforming finance mechanism to strengthen its ecologic directedness; legislation improvement.

4. Forestry's financial support should be considered as a system of institutions connected with financial support of investment environment for forest resources development, their protection, use, strengthening of forest's social and economic functions in accordance with demands of ecology and efficient economy.

5. In certain regions there should be formed state-private partnership institutes for efficient entrepreneurship development in forestry sector of economy

6. It is necessary to develop an efficient national government program of protecting remaining and planting new field-protection tree lines.

7. There should be ensured transparency of the country's forests and forestry management by publishing accounts of forestries activity regardless of ownership forms, as well as by issuing information materials on the state of forests. The results of forests inventories and forestry running plans should be opened for public access. It is necessary to maintain close contacts with local population in order to involve people in making managerial decisions in forest management sphere on certain territories.

8. In certain areas there should be formed state-private partnership institutes for creating an institutional environment in forestry, including cluster formations.

9. It is necessary to develop (with involvement of scientists, practitioners, and ecologists) and to approve in accordance with standing procedures the instruction on forest management in Ukraine as a balanced ecology-economic national normative act that should ensure a stable development of forestry in Ukraine and clearly reflect the duties of each party involved.

10. To develop a basic document (a draft law or the Cabinet of Ministers decree) that would ensure (with taking into account European experience) the formation of finance and resource basis for forestry business development at all territories of the naturepreserves lands.

11. In order to improve forest management system and considering the experience of Poland, Lithuania, and Canada, it is expedient to subordinate state bodies of forestry management to the Ministry of Ecology and Natural Resources of Ukraine as the supreme state executive power body responsible for the state of environment and natural resources.

12. To join the "European Union's Forest Strategy" and to implement its most important, strategic directives in forestry policies for national interests of Ukraine. Economic stimulating of forestry development should be efficient and limited within specific time period.

In forestry of Ukraine in accordance with the market changes in economy of the state, there are taking place normative-legal, structural, organizational economically substantiated changes directed at forestry management improvement, forests 
productivity increase, and bringing their area to the optimum size by implementing foreign experience among other measures.

High efficiency of forestry running is attained by ensuring its profitability in the course of the use of forest resources and forest's useful qualities.

Forestry influences the use of land, labor, and capital for goods and services production obtained from the forest, while economy lets us understand what ways we should take in order to better satisfy people's needs.

In the XXI century the national forestry policies should be directed first of all at increasing the forestated lands' area and prevention of vulnerable forest ecosystems' degradation that are instigated by destructive anthropogenic activity, as well as measures on strengthening forests' stability, including genetic stability, and their bio-diversity should be taken; forest use in such areas will be conducted without total wood cutting.

In order to secure forestry's stable development, it is necessary to change for the better mentality of all employees at all management levels of the state economy of Ukraine. Forestry will develop successfully alongside with the national economy only after we succeed in bringing up a young generation of Ukrainians in the spirit of high patriotism and love of native land, its ecological and spiritual heritage. This love on genetic level should penetrate the layers of generations to cherish traditions of Ukrainian spirituality in the state and in the family.

\section{References}

Alekseiev S.S. The theory of law issues, vol. 1, 1972, 395p.

Antonenko I.Ya. Formation of market-orientated finance-economic mechanism of Ukraine's forest resources sphere's development. AgroSvit: information-analytical journal, 2011, no. 13/14, pp. 7 - 12.

Decree of the President of Ukraine "On the Statute of the State agency of forest resources of Ukraine" of April 13, 2011 No 458/2011. Official bulletin of the President of Ukraine of 20.04.2011, no 11, art. 621. (As of 01.03.2014 it controls 68 per cent of Ukraine's forests) Web-resource. Access mode: http://dklg.kmu.gov.ua/forest/control/uk/publish/article?art id=6294\&cat id=34019

Demydiuk S.M. Problem issues of business activity development in forest sector. National University of Aquatic Industry and Use of Natural Resources. "Economy" series, issue 1 (53), 2011, pp. 51 - 56.

Forestry science and innovations. (web-resource), access mode: https://tlu.kiev.ua/nasha-dijalnist/profsiinopro-lis/lisova-nauka-ta-innovaciji.html

Golyan V.A. Problems of business activity economic regulating in forest sector of Ukraine. Modern economy. Problems and solution, 2010, no. 5 (5), pp. $24-33$.

Golyan V.A. State-private partnership as efficient form of entrepreneurship in forest sector. Agrosvit, 2010, no. 15 , pp. $2-9$.

Golyan V.A., Demydiuk S.M., Gordiychuk A.I. Improvement of ecology-economic regulation of forest management business: national reality and expediency of foreign experience implementation. Investments, practice, and experience, no. 12/2012, pp. 26 - 28.

Gorbyk V.M. Forestry policy forming: current state and development perspectives. Economy and State, 2006, no 11 , pp. $73-76$.

Hvesyk. M.A. Institutional model of use of natural resources in conditions of global challenges [Text]: monography. M.A. Hvesyk, V.A. Golyan. Kiev: Condor Publ., 2007, 480 p.

Ilnytska-Hykavchuk G. Ya. Financial mechanism of ecologically balanced forest management: Author's thesis for Candidate of economic sciences. Rivne, 2009, 22 p.

Kapruk A. Forest management finance-credit regulating: institutional preconditions and possible alternatives. Economist, no. 3, 2011, pp. $36-38$.

Kolisnyk B.I. Investment support of forest managing complex' development: current state and search for additional sources. Investments: practice and experience, 2008, no. 7, pp. 3 - 7. 
Koval Ya. Ownership relationships in the context of restructuring forest sector of Ukraine. Economy of Ukraine, 2001, no. 6, pp. 63 - 67.

Kozhukhov N.I. Modern level of business activity in the forests of agricultural organizations. Forestry, 2004, no 4,480 p.

Labenko O.M. Financing of forests restoring projects. Science Bulletin of National University of Bio-resources and Use of Natural Resources of Ukraine. 181st edition, part 5. "Economy, agriculture management, business" series: Collected works, Kyiv, NUBiPU publ., 2013, pp. 137 - 144.

Law of Ukraine "On investment activities". The Verkhovna Rada Bulletin, 2002, no 36, p. 266.

Melnyk T.D. The mechanism of raising investment potential of a region's forestry complex. National University of Aquatic Resources and Use of Nature Resources. "Economics" series. Edition 4 (56), 2011, pp. 181 - 186.

Mishenin Ye.V. Socio-ecologic responsibility of forest complex enterprises. Stable development and ecologic safety of society in economic transformations: materials of the Second science-and-practical conference. Bakhchisaray, September 23 - 24, 2010 held at NDI of stable development and use of natural resources, DU "Institute of economy of nature resources use and stable development at National Academy of Science of Ukraine", the Crimean Institute of State higher education establishment "KNEU after V. Hetman". Simferopol: Phoenix Publ., 2010, pp. 235 - 237.

Mishenin Ye., Mishenina G. Conceptual foundations of state-private partnership mechanisms development in the forest resources sphere. Economist, no.12 (December), 2010, pp. 23 - 26.

Mishenin Ye.V., Mishenina G.A., Yarova I. Ye. Ecology-economic and social points of forestry development on entrepreneurial basis. Sumy National Agricultural University Bulletin. "Economy and management" series, edition. 3 (51), 2012, pp. 3 - 10.

Mishenina G.A. Ecology-economic basis of entrepreneurship development in the forest resources sphere: Dissertation thesis for Candidate of economic sciences. Sumy, 2010, 260 p.

Mishenina G. A. Rent relationships in natural resources use: modern practices and perspectives. Stable development and ecology safety of society in economic transformation: materials of the Third science-andpractical conference. Bakhchisaray, September 15 - 16, 2011, held at NDI of stable development and use of natural resources, DU "Institute of economy of nature resources use and stable development at National Academy of Science of Ukraine", the Crimean Institute of State higher education establishment "KNEU after V. Hetman". Simferopol: Phoenix Publ, 2011, pp. 178 - 180.

On approving the Concept of forestry development reforming. Official Bulletin of Ukraine, 2006, no 16, art. 1207.

On approving the Concept of the national ecology policies of Ukraine to 2020. Official Bulletin of Ukraine, 2007, no 79, art. 2961.

Poliakova L.V. International issues of providing financial assistance to stable forest management. Scientific reports of NUBiP, 2011, no. 4 (26), pp. 112 - 119.

Rogach S.M. Directions of balancing institutional support of Ukraine's forestry complex' development. Sumy National Agrarian National University Bulletin. "Finances and credit" series, 2013, no.1, pp. 118 - 126.

Savchuk O.O. Procedural relationships in forestry legislation of Ukraine: a monograph. O.O. Savchuk. Edited by A.P. Hetman. Kharkiv: "Finart" Publ, 2016, 242 p.

Shubalyi O.M. Methodological foundations of the region forestries' competitive positions. Economy and State, 2010, no 1, pp $62-66$.

Shumliansky B.F. Financial support as a foundation of forming investment medium for forest sector development. Investments: practice and experience. Economic science, no. 15/2015, pp. 61 - 66.

Statute on oblast forestry and hunting offices of State forest resources agency approved by the Order of Ministers of agriculture and food supply of Ukraine of 21.03.2012 No 134: Official Bulletin of Ukraine, 2012, no 37, art. 1408.

Statute on the Ministry of Ecology and Natural Resources approved by the Decree of the President of Ukraine of April 13, 2011 No 452/2011: Official Bulletin of Ukraine, 2011, no 31, art. 1326.

Syniakevich I. Eco-policy instruments: theory and practice. Lviv: ZUTsK Publ., 2003, 188 p.

Yakimov A.Yu. The status of a subject of law (theoretical issues). The state and law, 2003, no 4, pp. $5-10$.

Yermolenko V.M. Property relationships of private agricultural enterprises: theory, legislation, practice: A monograph. Kyiv, Master of the XXI century publ., 2005, 304 p.

Web-resource. Access mode: http://www.menr.gov.ua/

Zinovchuk N., Vasyliak N. Forest resources sphere development stimulating: system contradictions and instruments of economic relationships realization. Economist, no 12, 2012, section "Economy of the use of natural resources", pp. $52-54$. 